\title{
Hazai kórházi antibiotikum-alkalmazás az elmúlt két évtizedben (1996-2015)
}

\author{
Benkő Ria dr. ${ }^{1}$ - Matuz Mária dr ${ }^{1}$ - Hajdú Edit dr. ${ }^{2}$ - Bor Andrea dr. ${ }^{2}$ \\ Doró Péter dr. ${ }^{1}$ - Viola Réka dr. ${ }^{1}$ - Soós Gyöngyvér dr. ${ }^{1}$
}

Szegedi Tudományegyetem, ' Gyógyszerésztudományi Kar, Klinikai Gyógyszerészeti Intézet, ${ }^{2}$ Általános Orvostudományi Kar, Szent-Györgyi Albert Klinikai Központ, I. Belgyógyászati Klinika, Infektológia Osztály, Szeged

\begin{abstract}
Bevezetés: A bakteriális rezisztencia közegészségügyet fenyegető probléma, amely mérsékelhető, lassítható megfelelő antibiotikum-alkalmazással. Célkitüzés: A hazai fekvőbeteg-ellátás szisztémás antibiotikum-felhasználásának bemutatása. Módszer: A kórházi antibiotikum-felhasználási adatokat az Egészségügyi Világszervezet anatómiai-terápiás-kémiai rendszere szerint osztályozták és a Defined Daily Dose metodika szerint kvantifikálták. A standardizálás kórházi betegforgalmi mutatókra, valamint - a nemzetközi összehasonlítás végett - populációra történt. Eredmények: A fekvőbetegszektor antibiotikum-felhasználása az elmúlt 20 évben mennyiségileg kiegyenlített volt $(22,4 \pm 1,5$ DDD/100 ápolási nap), mintázata folyamatos változáson ment keresztül. Megfigyelhettük a parenteralis készítmények alkalmazásának emelkedését (1996-ban 26,4\%, 2015-ben 41,6\%). Kiemelendő a felhasználás összetételének homogenizálódása az amoxicillin-klavulánsav térnyerése miatt, a fluorokinolon (2,3 vs. 4,2 DDD/100 ápolási nap) és a harmadik generációs cefalosporinfelhasználás ( 1,0 vs. 2,9 DDD/100 ápolási nap) jelentős emelkedése, valamint a szúk spektrumú penicillinek kiszorulása. Köpetkeztetés: A hazai kórházi antibiotikum-felhasználás mennyiségileg alacsony. Ez, illetve a felhasználás mintázatában tapasztalt, nemzetközi mércével is alátámasztott alul- vagy felülreprezentált felhasználás okának és indokoltságának megítélése további vizsgálatot igényel. Orv. Hetil., 2016, 157(46), $1839-1846$.
\end{abstract}

Kulcsszavak: antibiotikum-felhasználás, kórházi ellátás, trend, mintázat, antibiotikum-surveillance

\section{Antibiotic use in the Hungarian hospitals in the last two decades (1996-2015)}

Introduction: Growing bacterial resistance threatens public health, which can be tempered by prudent antibiotic use. Aim: To quantify systemic antibacterial use in Hungarian hospitals. Method: Consumption data were analysed using the Anatomical-Therapeutic-Chemical - Defined Daily Dose (ATC/DDD) methodology. Data were standardized for patient turnover and also for population to enable international benchmarking. Results: Hospital antibiotic use was quite constant $(22.4 \pm 1.5 \mathrm{DDD} / 100$ patient-days $)$, but its composition changed substantially. The use of parenteral products rose gradually (in $199626.4 \%$ and in $201541.6 \%$ ). The pattern of use was homogenised due to the headway of co-amoxiclav use. A substantial increase of fluoroquinolone (2.3 vs. $4.2 \mathrm{DDD} / 100$ patient-days) and third generation cephalosporin ( 1.0 vs. $2.9 \mathrm{DDD} / 100$ patient-days) use was detected. In parallel the use of narrow spectra penicillins diminished. Conclusion: Hungarian hospital antibiotic use is low. The causes and the justification of this low use together with the internationally outstanding use of certain antibacterials should be addressed in future studies.

Keywords: antibacterial use, hospital care sector, trends, patterns of antibacterial use, antibacterial surveillance

Benkó, R., Matuz, M., Hajdú, E., Bor, A., Doró, P., Viola, R., Soós, Gy. [Antibiotic use in the Hungarian hospitals in the last two decades (1996-2015)]. Orv. Hetil., 2016, 157(46), 1839-1846.

(Beérkezett: 2016. május 18.; elfogadva: 2016. augusztus 30.) 


\section{Rövidítések}

ATC $=$ (Anatomical-Therapeutic-Chemical classification) gyógyszerek anatómiai-terápiás-kémiai osztályozása; DDD = (Defined Daily Dose) átlagos napi felnőtt, fenntartó dózis; $\mathrm{ECDC}=($ European Centre for Disease Prevention and Control) Európai Járványvédelmi és Betegségmegelőzési Központ; ESAC-Net $=($ European Surveillance of Antibacterial Consumption Net) Európai antibiotikum-felhasználás surveillance adatbázis; $\mathrm{KSH}=$ Központi Statisztikai Hivatal; MRSA = (methicillin-resistant Staphylococcus aureus) meticillinrezisztens Staphylococcus aureus; OEK = Országos Epidemiológiai Központ; OEP = Országos Egészségbiztosítási Pénztár; $\mathrm{WHO}=$ (World Health Organisation) Egészségügyi Világszervezet

A bakteriális rezisztencia az egyik legfenyegetőbb globális probléma. Megjelenésével racionális antibiotikumalkalmazás mellett is számolnunk kell, azonban a szuboptimális antibiotikum-használat ezt a folyamatot nagymértékben felgyorsítja. A jelenlegi helyzetet extrapolálva a szakemberek pár évtizeden belül vizionálják a 'preantibiotikumos éra' megjelenését, ami az antibiotikumok felfedezése előtti időszakot fogja megjeleníteni $[1,2]$. Ezt az időszakot megfelelő antibiotikum-politikával (úgynevezett antibiotic stewardship) [3] lehet kitolni, ezzel időt nyerve új hatásmechanizmusú antibiotikumok kifejlesztésére. A problémás területek feltérképezéséhez, így az antibiotikum-politika beavatkozási pontjainak meghatározásához, első lépés az aggregált gyógyszer-felhasználási adatok ismerete [4], folyamatos követése és elemzése. Jelen munkában a szisztémás (ATC-kód: J01) kórházi antibiotikum-felhasználás mennyiségének, öszszetételének, trendjének elemzését és nemzetközi összehasonlítását tűztük ki célul.

\section{Módszer}

A hazai kórházi szektor éves, 1996-2015 közötti időszakra vonatkozó szisztémás antibiotikum- (J01 ATCcsoport) fogyasztási adatai a kórházak részére történő nagykereskedelmi eladásokon alapulnak (IMS Health). Az elemzett felhasználási adatokban a hazai gyógyszerpiacon nem elérhető, úgynevezett egyedi importkészítmények, illetve a gyógyszeradományok felhasználása nem szerepel, azonban ez utóbbi szerepe marginális. A készítmények hatóanyagainak csoportosítását és az elemzést az egészségügyi világszervezet (WHO) által javasolt anatómiai-terápiás-kémiai (ATC-) index, illetve Defined Daily Dose (DDD-) metodika alapján végeztük [5]. A DDD az átlagos napi, felnőtt, fenntartó dózist jelenti a hatóanyag fó indikációjában, mérsékelt súlyosságú infekcióban. Az antibiotikum-felhasználást a 2015ben érvényes DDD-értékek figyelembevételével számoltuk [5]. A felhasználási adatokat különféle betegforgalmi adatokra standardizáltuk (DDD/100 ápolási nap, DDD/1 elbocsátott beteg), illetve - mivel ezen technikai egységek nemzetközi hasonlításának korlátai vannak - adatainkat kifejeztük a legáltalánosabban alkalma- zott DDD/1000 lakos/nap technikai egységben is. A nemzetközi irodalomnak megfelelően külön elemeztük az úgynevezett kórházspecifikus antibiotikumok alkalmazását [6]. A standardizálásra használt betegforgalmi adatok (ápolási napok, elbocsátások) az Országos Egészségbiztosítási Pénztár (OEP) jelentéseiből származtak [7], míg a népességi adatok a Központi Statisztikai Hivatal (KSH) kimutatásain alapulnak [8]. Az összesített fogyasztás és a kiemelt antibiotikum-csoportok felhasználásának nemzetközi összehasonlítására az Európai Járványvédelmi és Betegségmegelőzési Központ (ECDC) antibiotikum-surveillancre vonatkozó adatbázisát (úgynevezett ESAC-Net - European Surveillance of Antibacterial Consumption) használtuk [9]. Az adatok feldolgozásához és megjelenítéséhez az MS Office programcsomag mellett az $\mathrm{R}$ (3.2.2) programot használtuk.

\section{Eredmények}

A kórházi szektor antibiotikum-felhasználása (ATC-fócsoport: J01) az összesített (kórházi + ambuláns) hazai antibiotikum-felhasználás 7,02 $\pm 0,6 \%$-át tette ki az elemzett években. A fertőzésellenes (ATC-föcsoport: J) szerek teljes csoportjának (ATC: J01 - szisztémás antibiotikumok, J02 - szisztémás antimikotikumok, J04 - tbc-ellenes szerek, J05 - szisztémás antivirális szerek) kórházi összesített felhasználását tekintve 100\%-nak, a szisztémás antibakteriális szerek részesedése 66,0\% vagy a feletti volt minden évben, így elmondható, hogy ez a csoport uralja a fertőzésellenes szerek felhasználását. Hazánkban 2015-ben körülbelül 300 különböző antibiotikum-készítmény volt forgalomban. A kórházi szektorban elérhető/használt antibiotikumokat csoportonként az 1. táblázat tartalmazza, míg az 1. ábra Magyarország kórházi antibiotikum-felhasználását mutatja.

Az 1. ábrán látható, hogy a felhasználás az évek során többé-kevésbé kiegyenlített volt, 2015-ben 100 ápolási napra vonatkoztatott 23,0 DDD-érték azt jelenti, hogy 100 ápolási napból 23 ápolási napon adtak antibiotiku-

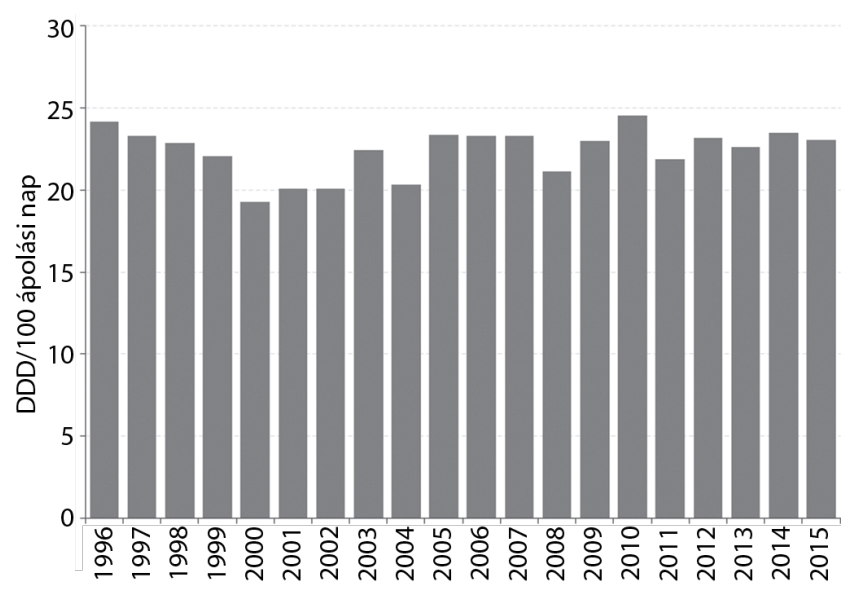

1. ábra | Hazai kórházi antibiotikum-felhasználás (1996-2015) 
1. táblázat | A kórházi szektorban elérhető antibiotikumok a vizsgált időtartam alatt. Dôlt betúvel kiemelve azon hatóanyagok, amelyeknek részesedése 2015 viszonylatában meghaladta az $1 \%$-ot*

Tetraciklinek (J01A)

Tetraciklinek (J01AA): doxycyclin, limeciclin, oxytetraciklin, tetraciklin, tigeciklin

Penicillinek (J01C)

Széles spektrumú penicillinek (J01CA): amoxicillin, ampicillin, piperacillin

Szük spektrumú, béta-laktamáz-érzékeny penicillinek (J01CE): benzatin benzylpenicillin, benzatin phenoxymethylpenicillin,

benzilpenicillin, penamecillin, fenoximetilpenicillin, prokain benzilpenicillin

Szúk spektrumú, béta-laktamáz rezisztens/stabil penicillinek (J01CF): oxacillin

Széles spektrumú penicillinek béta-laktamáz-gátlóval (J01CR): amoxicillin és klavulánsav, ampicillin és szulbaktám, piperacillin és tazobaktám

Cefalosporinok és egyéb béta-laktámok (J01D)

Első generációs cefalosporinok (J01DB): cefazolin, cefadroxil, cefalexin, cefalexin

Második generációs cefalosporinok (J01DC): cefuroxim, cefaklor, cefamandol, cefoxitin, cefprozil

Harmadik generációs cefalosporinok (J01DD): ceftriaxon, cefotaxim, cefixim, cefoperazon, ceftazidim, ceftibuten

Negyedik generációs cefalosporinok (J01DE): cefepim

Karbapenemek (J01DH): imipenem és cilasztatin, meropenem, doripenem, ertapenem

Szulfonamidok (J01E)

Szulfonamidok és trimetropim (J01EE): szulfadimidin és trimethoprim, szulfamethoxazol és trimethoprim

Makrolidok, linkózamidok és sztreptograminok (J01F)

Makrolidok (J01FA)

Rövid hatástartamú makrolidok: erithromycin, spiramycin

Közepes hatástartamú makrolidok: clarithromycin, josamycin, roxithromycin

Hosszú hatástartamú makrolidok: azitromycin, dirithromycin

Linkózamidok (J01FF): clindamycin

Streptograminok (J01FG): quinupristin/dalfopristin

Aminoglikozidok (J01G)

Egyéb aminoglikozidok (J0lGB): gentamycin, amikacin, netilmycin, streptomycin, tobramycin

Kinolonok (J01M)

Első generációs kinolonok: nalidixsav, norfloxacin

Második generációs kinolonok: ciprofloxacin, levofloxacin, ofloxacin, pefloxacin

Harmadik generációs kinolonok: moxifloxacin, trovafloxacin

Egyéb antibiotikumok (J01X)

Glikopeptidek (J01XA): teikoplanin, vancomycin

Imidazolszármazékok (J01XD): metronidazol

Egyéb: colistin, fosfomycin, fuzidinsav, linezolid, nitrofurantoin, polymyxin B, spectinomycin

*Egyedi importkészítmények nem szerepelnek a táblázatban.

mot átlagos dózisban. (Vagyis például egy adott nap 100 bent fekvő beteg közül 23 kapott antibiotikumot, átlagos dózisban.) A másik betegforgalmi változóra standardizált egységben kifejezett antibiotikum-fogyás $(1,83$ DDD/1 elbocsátott beteg 2015-ben) azt jelenti, hogy átlagosan minden, kórházból távozott betegre kétnapos átlagos dózisú antibiotikum-kúra jutott. A nemzetközi hasonlításra alkalmas egységben kifejezett fogyás 2015ben 1,22 DDD/1000 lakos volt, amely pedig úgy értelmezhető, hogy minden egyes naptári napon 1000 lakos közül 1 beteget kezelnek kórházban antibiotikummal.

A szisztémás antibiotikumok felhasználásának zömét az orális készítmények adták, azonban a tanulmány évei- ben a parenteralis készítmények részesedésének folyamatos emelkedését (1996: 26,4\%; 2015: 41,6\%) figyelhettük meg.

A 2. ábrán látható az egyes antibiotikum-csoportok évenkénti relatív részesedése a kórházi antibiotikum-felhasználásból. A kórházi antibiotikum-felhasználást mindvégig a béta-laktám antibiotikumok uralták, a tetraciklinek, szulfonamidok és aminoglikozidok csökkenő, a makrolidok és linkózamid, a kinolonok és az egyéb antibiotikumok növekvő szerepe mellett.

A 10 legnagyobb felhasználású antibiotikumot a tanulmány nyitó, illetve záró évében a 2. táblázatban foglaltuk össze, a 20 éves trendet a „top” öt hatóanyag vo- 


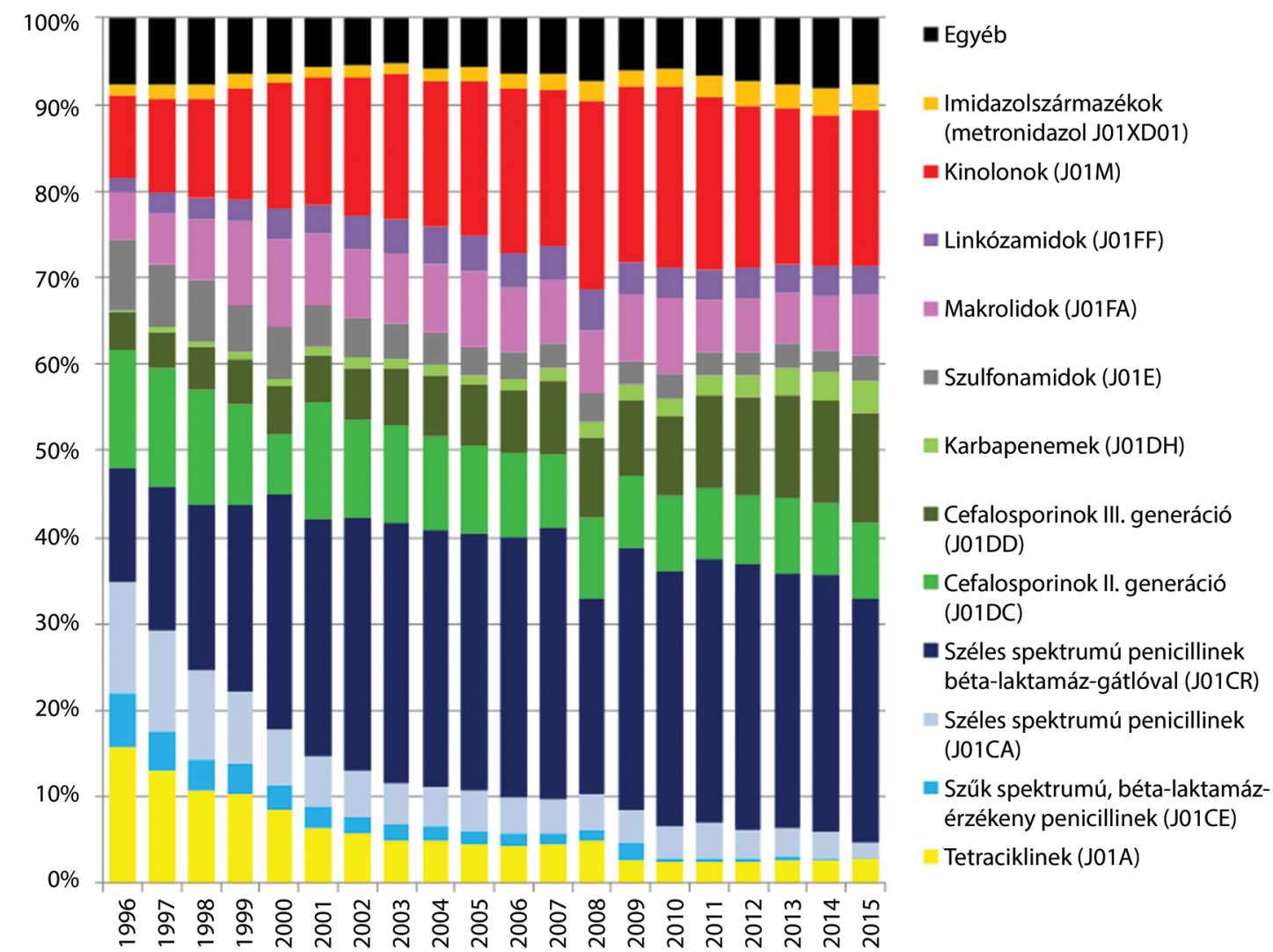

2. ábra

| A kórházi antibiotikum-felhasználás összetétele az egyes években

natkozásában pedig a 3. ábrán. Jellemző a felhasználás „homogenizálódása”, ami leginkább a leggyakrabban használt hatóanyag részesedésének növekedése kapcsán szembeötlő (2. táblázat 1. sora).

A penicillincsoport közel változatlan mértékü (minimum-maximum: 6 vs. 8 DDD/100 ápolási nap) felhasználása mellett a csoport felhasználási mintázata nagymértékben megváltozott (2. ábra). 1996-ban a szúk spektrumú készítmények még a penicillincsoport felhasználásának egyötödéért feleltek, majd fokozatosan csökkenő részesedés mellett, 2010-től elenyésző a felhasználásuk (2. ábra). Ezzel párhuzamosan a klavulánsavval kombinált széles spektrumú penicillinkészítmények (döntően az amoxicillin-klavulánsav) relatív részesedése 40\%-ról 90\% fölé emelkedett (2. ábra) a penicillincsoporton belül. Az összesített antibiotikum-felhasználást tekintve is tekintélyes az amoxicillin-klavulánsav részesedése: 2015 -ben top hatóanyagként önmagában a kórházi antibiotikum-felhasználás mintegy 30\%-áért felelt (2. táblázat, 3. ábra).

A másik béta-laktám-csoport, a cefalosporinok tekintetében megfigyelhettük a harmadik generációs készítmények térnyerését (mind abszolút, mind relatív értelemben) a második generációs készítmények kárára (2. ábra). A második generációs cefalosporinok közül egyedül a cefuroxim őrizte meg a felhasználás mértékét (2. táblázat, 3. ábra), a cefamandolfelhasználást 2008ban detektáltuk utoljára az adatbázis alapján, a cefaklor alkalmazása az évek során szintén elapadt. A harmadik generációs készítmények előtérbe kerülése a toplistán is nyomon követhető, 2015-ben a ceftriaxon a második legnagyobb mennyiségben alkalmazott hatóanyag volt a kórházi szektorban (2. táblázat). A makrolidcsoport vo-

2. táblázat A hazai kórházi szektorban leggyakrabban használt 10 antibiotikum, 1996 vs. 2015. Dólt betüvel jelölve azok a hatóanyagok, amelyek mindkét záró évben szerepeltek a toplistán.

\begin{tabular}{|c|c|c|c|c|c|}
\hline \multicolumn{3}{|c|}{1996} & \multicolumn{3}{|c|}{2015} \\
\hline & $\begin{array}{l}\text { DDD/ } \\
100 \\
\text { ápolási }\end{array}$ & $\%$ & & $\begin{array}{l}\mathrm{DD} / \\
00 \\
\text { polási }\end{array}$ & $\%$ \\
\hline Doxycyclin & 3,8 & 16 & $A M C$ & 6,3 & 27,4 \\
\hline$A M C$ & 2,8 & 12 & Ceftriaxon & 2,6 & 11,2 \\
\hline Ampicillin & 2,3 & 9,7 & Ciprofloxacin & 2,2 & 9,3 \\
\hline Cefuroxim & 2,1 & 8,5 & Cefuroxim & 2,0 & 8,7 \\
\hline$S M X / T M P$ & 1,9 & 7,8 & Levofloxacin & 1,3 & 5,6 \\
\hline Ciprofloxacin & 1,0 & 4,0 & Clarithromycin & 1,2 & 5,4 \\
\hline Penamecillin & 0,9 & 3,9 & Clindamycin & 0,8 & 3,3 \\
\hline Ofloxacin & 0,7 & 3,0 & Metronidazol & 0,7 & 3,0 \\
\hline Cefaclor & 0,7 & 2,8 & $S M X / T M P$ & 0,7 & 2,8 \\
\hline Roxithromycin & 0,6 & 2,5 & Doxycyclin & 0,6 & 2,8 \\
\hline
\end{tabular}

AMC $=$ amoxicillin és klavulánsav; SMX $/ \mathrm{TMP}=$ szulfametoxazol és trimetoprim. 
natkozásában jellemző a szélesebb spektrumú/kedvezőbb kinetikájú hatóanyagok térnyerése (2. táblázat, 3. ábra). A fluorokinolonok abszolút (1996: 2,3 DDD/100 ápolási nap vs. 4,2 DDD/100 ápolási nap) és relatív felhasználásának emelkedése (1996: 9,6\% az összfogyásból vs. 2015: 18,0\%) a legszembetűnóbb az évek során (2. ábra, 2. táblázat). A csoporton belül a ciprofloxacin volt a legközkedveltebb hatóanyag (közel megkétszereződött abszolút és relatív felhasználással), megfigyelhető volt a racém ofloxacin lecserélődése a balra forgató enantiomerre (levofloxacin), illetve a másik Gram-pozitív, valamint anaerob spektrummal is rendelkező hatóanyag (moxifloxacin) megjelenése (2001), majd felhasználásának emelkedése.

Szintén megemlítendő az ATC-besorolás szerint az egyéb csoportba (ATC: J01X) tartozó, anaerobok ellen hatékony parenteralis metronidazolfelhasználás megduplázódása az utóbbi 10 évben (2005: 0,35 vs. 2015: 0,71 DDD/100 ápolási nap), illetve a linkózamidcsoportba tartozó clindamycinfelhasználás emelkedése (főleg a tanulmány első felében) és így a 10 legnagyobb mennyiségben használatos antibiotikumok közé kerülése (2. táblázat).

A parenteralis készítmények felhasználása fokozatosan emelkedett az évek során (1996: 6,4 DDD/100 ápolási nap vs. 2015: 9,3 DDD/100 ápolási nap), míg változásának összetételét elemezve közel azonos tendenciák érvényesülnek, mint az összesített kórházi antibiotikumfelhasználásra.

A 2000-es évek elejétől az úgynevezett kórházspecifikus antibiotikumok részesedése fokozatos emelkedést mutatott (4. ábra), elsősorban a harmadik generációs cefalosporinok, valamint a karbapenemek és a glikopeptidek növekvő felhasználása miatt.

\section{Megbeszélés}

Hazánk azon európai országok közé tartozik, ahol rendelkezésre állnak, elemzik és az Európai Járványvédelmi és Betegségmegelőzési Központ (ECDC) felé jelentik a fekvőbetegszektor fertőzésellenes szereinek felhasználását. Európai viszonylatban a hazai kórházi antibiotikumfelhasználás mennyisége alacsony (5. ábra), 2014-ben egyedül Hollandia felhasználása volt alacsonyabb. További vizsgálatot érdemel, hogy a hazai alacsony antibiotikum-alkalmazás követendő példa (tudnillik „optimális mértékű alkalmazás”), vagy az alacsony felhasználás hátterében antibiotikum-hozzáférésbeli hiány (például financiális), illetve aluldozírozás áll-e, tudnillik az antibiotikum-aluldozírozás rezisztenciaindukáló hatása ismert.

Európai összevetés alapján penicillincsoport-felhasználás az összesített kórházi antibiotikum-felhasználáshoz hasonlóan 2014-ben az alsó kvartilisben helyezkedett el. Az egyes penicillincsoportok vonatkozásában: míg a svédek és norvégek szúk spektrumú penicillineket alkalmaztak (ATC: J01CE és J0lCF) több mint 50\%-os arányban 2014-ben, addig az adatokat jelentő európai országok közül nálunk alkalmaztak ezekből a penicillinekből a legkevesebbet (2015-ben 1\% alatti volt a penicillincsoporton belüli részesedésük). Az ambuláns szektorban hasonló átrendeződésnek voltunk tanúi $[10,11]$.

A szúk spektrumú penicillinfelhasználás drámai csökkenése magyarázható azzal, hogy először a béta-laktamáz-stabil (ATC: J01CF) penicillinkészítmény (oxacillin) forgalmazását szüntették meg (2003), majd a béta-laktamáz-érzékeny (ATC: J01CE) penicillinkészítmények közül érintett kettőt a regisztráció törlése (Penicillin G Na Sandoz: 2012. január, Promptcillin: 2014. április), míg a jelenleg még forgalomban lévő rövid, illetve hosszú hatású parenteralis készítmények elérhetősége a hosszúra nyúlt „átmeneti” (Penicillin 1 ME: 2014. januártól; Retardillin: 2013. januártól) - gyártási problémákból adódó - termékhiány miatt jelenleg csak egyedi importtal lehetséges az Országos Gyógyszerészeti és Élelmezésügyi Intézet adatbázisa szerint.

A béta-laktamáz-gátlóval kombinált széles spektrumú penicillinek penicillincsoporton belüli részesedése az európai országok közül egyedül Szlovákiában volt magasabb 2014-ben [9]. A jelenség okát részben magyarázza a korábbi beidegződés: „önálló” amoxicillinkészítmény hazánkban három évvel később került forgalomba, mint a klavulánsavval kombinált verziója. Mivel indikációhoz kötött antibiotikum-felhasználási adatok a kórházi szektorra nem elérhetők, így csupán annyi konklúziót vonhatunk le a szúk spektrumú penicillinkészítmények alacsony alkalmazási arányáról, hogy a terápiaszúkítés (streamlining) a kórházakban nem megoldott, aminek hátterében több ok is feltételezhető: a mikrobiológiai mintavételek elmaradása, a mikrobiológiai eredmények igazoltan lassú közlése [12], illetve a lelet értelmezésbeli problémája. Az ampicillinfelhasználás csökkenése az utóbbi években ellátásbeli gondokkal is magyarázható, a készítményt egyedi importként hozták be (például Gobemicina néven, ami adatforrásainkban nem szerepel).

A klavulánsavval kombinált aminopenicillinek bár létjogosultak bizonyos fertőzésben (például kórházi felvételt igénylő közösségben szerzett pneumonia), növekvő felhasználása nem magyarázható a rezisztenciatrendekkel, hiszen az egyik leggyakoribb légúti kórokozó, a pneumococcusok penicillinrezisztenciája egyrészt nem emelkedett, másrészt az nem is béta-laktamázhoz kötött [13].

Az egyes cefalosporingenerációkat tekintve hazánkban a harmadik generációs készítmények relatív felhasználása magas, a második generációsaké átlagos, míg az első és negyedik generációs készítmények relatív felhasználása alacsony a 2014. évi európai surveillance-adatok alapján. Az első generációs cefalosporinok alacsony alkalmazási aránya meglepő, hiszen számos mútéttípusban (mellkassebészet, cardiovascularis sebészet, érsebészet, idegsebészet, bizonyos ortopédiai/traumatológiai mütétek, bizonyos gastrointestinalis mütétek, nőgyógyászati mütétek) ez az első választandó profilaktikus antibiotikum $[13,14]$, s bár voltak átmeneti ellátásbeli problémák, ez 


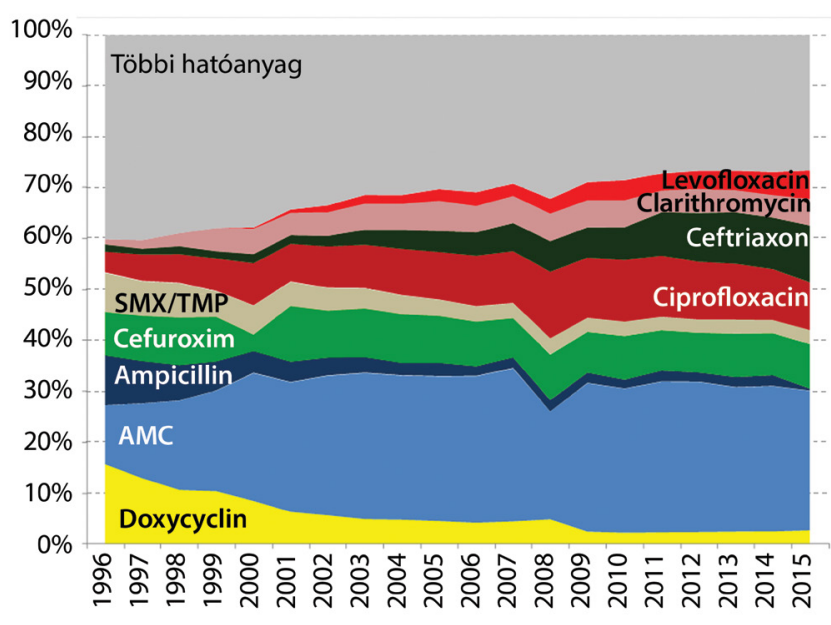

3. ábra

Az öt legnagyobb felhasználású hatóanyag relatív részesedése a
kórházi antibiotikum-felhasználásból a tanulmány (1996-2015)
egyes éveiben

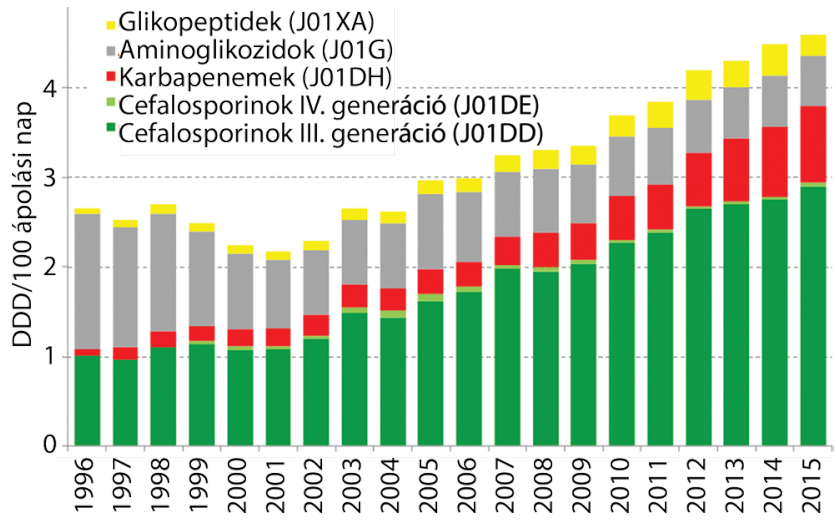

4. ábra

A kórházspecifikus antibiotikumok felhasználása az egyes évek-
ben

nem indokolhatja a hatóanyagcsoport ilyen mérvű kiszorulását. A negyedik generációs készítmények ritka alkalmazását egyedül az árkülönbség magyarázhatja, hiszen spektruma az antipseudomonas harmadik generációs cefalosporinokhoz hasonló, és számos fertőzés kezelésében létjogosultsága van (otthon szerzett intraabdominalis infekcióban, súlyos pneumoniában, bőr-, lágyrész-, húgyúti fertőzésben, nosocomialis meningitisben). Tapasztalataink szerint a harmadik generációs készítményeket metronidazollal kombinálva előszeretettel alkalmaznak hasi mütétekhez kapcsolódó profilaxisban, illetve hasi fertőzések kezelésére. Az Országos Epidemiológiai Központ honlapján elérhető 2014-es adatok szerint az E. coli törzsek harmadik generációs cefalosporinok elleni rezisztenciája ugyan $10 \%$ alatti, azonban a Klebsiella pneumoniae törzseké $20 \%$, ami miatt megfontolt alkalmazásukra szükség lenne. A makrolidok hazai kórházi felhasználása átlagos, európai mércével részese- désük az antibiotikum-felhasználáson belül a felső kvartilisbe esik. A clarithromycin és az azitromycin térnyerése indokolható a kedvezőbb farmakokinetikával és a Grampozitív (clarithromycin), illetve Gram-negatív (azitromycin) elleni fokozott aktivitással, továbbá a kedvezőbb mellékhatásprofillal [15]. A hatóanyagváltást részben magyarázhatja, hogy egyedül a clarithromycinből és az azitromycinből van parenteralis gyógyszerforma, illetve a generikumok jelenléte miatt jelentős az árverseny. Hazánkban, az európai országok többségéhez hasonlóan, a közepes hatástartamú makrolidkészítményeket alkalmazták leggyakrabban. Érdekesség, hogy míg hazánkban rövid hatástartamú makrolidok (például erithromycin, spiramycin) teljesen kiszorultak a gyakorlatból, addig Norvégiában a makrolidfelhasználás több mint 50\%-át, Svédországban több mint 40\%-át tették ki [9], köszönhetően a skandinávoknál tapasztalt sokkal szigorúbb gyógyszer-regisztrációnak.

A linkózamidok (clindamycin) felhasználása mind abszolút, mind relatív értelemben az európai országok felső kvartilisébe tartozik. Hasonlókat tapasztaltunk az ambuláns ellátásban is [11], oka nem ismert. Hazánk fluorokinolonfelhasználása közepes az európai országok rangsorában, a fluorokinoloncsoport kórházi antibiotikum-fogyáson belüli részesedése tekintetében viszont az egyik legmagasabb (6. ábra). A csoporton belül, a többi európai országhoz hasonlóan, a második generációs kinolonok felhasználása a legmagasabb, míg a harmadik

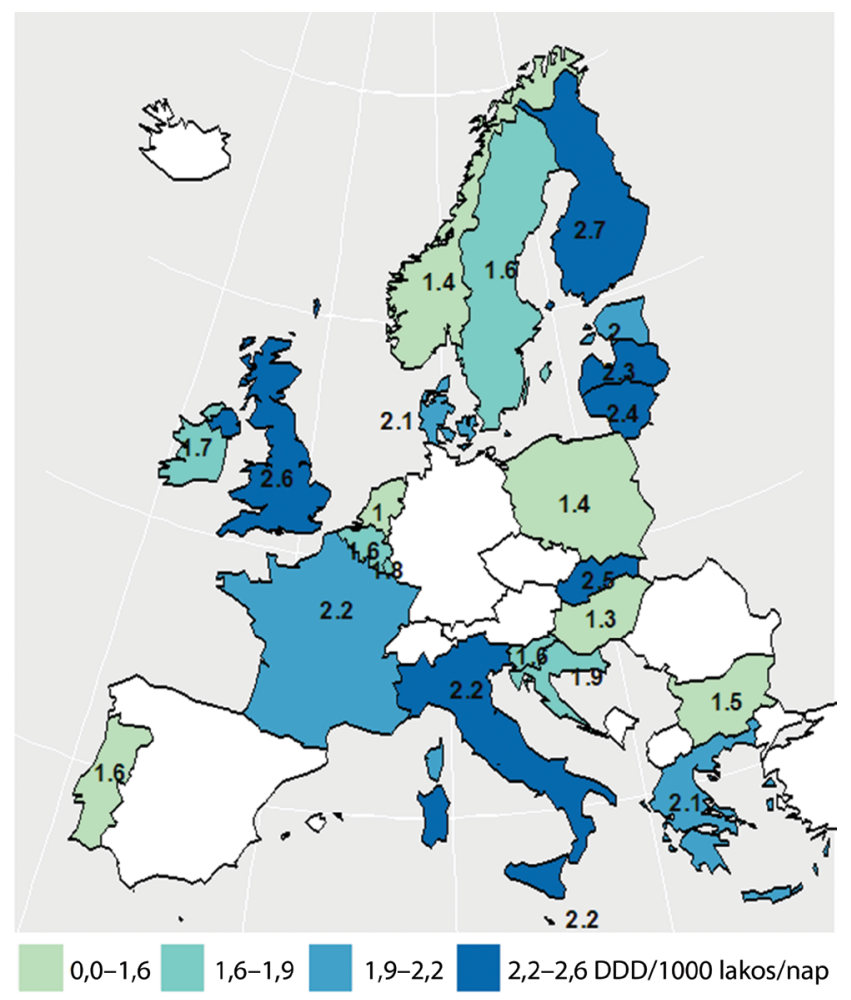

5. ábra $\quad$ Az európai országok kórházi antibiotikum-felhasználásának mértéke (DDD/1000 lakos/nap), 2014. Az ábra a European Surveillance of Antimicrobial Consumption Network (ESACNET) adatbázis adatain alapulnak. Fehér: nincs adat 


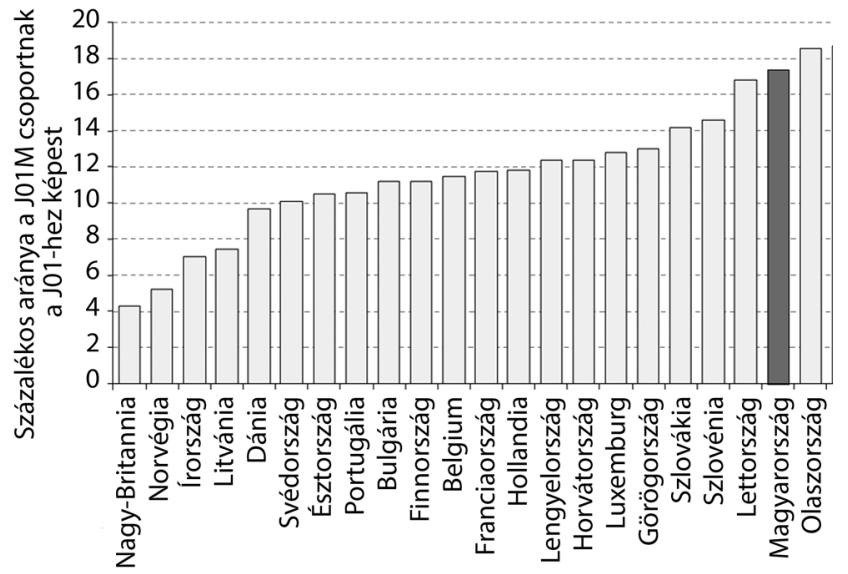

6. ábra

Az európai országok relatív kinolonfelhasználása a kórházi szektorban, 2014

generációs készítmények fogyásának megjelenése az európai országok mintegy felében, köztük hazánkban figyelhető csak meg. Nem ismert, hogy a nem megfelelö indikáció, a magasabb dózisok, a hosszabb kezelés vagy a terápiaszúkítés hiánya áll-e a magas fluorokinolonfelhasználás hátterében. A fluorokinolonok rezisztenciaindukáló hatása különösen nagy [16-18], és hazánkban az invazív izolátumok fluorokinolonrezisztenciája minden vizsgált baktériumtörzs esetén magasabb, mint az európai átlag [19]. Ezenkívül az ECDC legutóbbi pontprevalencia-vizsgálata alapján a Clostridium difficile-fertőzések hazai aránya rendkívül magas [16], ami mögött részben a magas fluorokinolonhasználat valószínúsíthetô. Mindezek alapján a megfontoltabb fluorokinolonalkalmazásra különös hangsúlyt kellene fektetni.

A szulfonamidok és tetraciklinek alkalmazási területe beszűkült, részben mert magas az E. coli szulfonamid- és pneumococcus tetraciklinrezisztenciája, másrészt mivel a magyar gyógyszerpiacon ezen csoportoknak csak az orális gyógyszerformái elérhetők, aminek kórházi indikációja/alkalmazása limitált. Az egyéb antibiotikum-csoport (ATC: J01X) felhasználása mind abszolút, mind relatív értelemben az európai medián alatti. A csoporton belül a glikopeptidek felhasználási aránya alacsony, annak ellenére, hogy a meticillinrezisztens Staphylococcus aureus (MRSA) törzsek előfordulási aránya az EU-átlag feletti [19], míg a metronidazolé magas az európai országok szisztémás antibiotikum-fogyásait tartalmazó ESAC-Net adatbázis 2014-es adatai alapján [9]. Ez utóbbira a magas Clostridium difficile-infekciószám adhat részben magyarázatot.

A kórházspecifikus antibiotikumok fent nem tárgyalt két csoportját tekintve a karbapenemek felhasználása emelkedett, európai viszonylatban a felhasználás abszolút értelemben alacsony, relatív értelemben inkább magasnak mondható, míg az aminoglikozidok alkalmazása csökkent, és az európai rangsor végén állt mind abszolút, mind relatív értelemben 2014-ben. Mivel az aminoglikozidok biztonságos alkalmazását lehetővé tevő terápiás gyógyszerszint-monitorozás csupán néhány kiemelt fekvőbeteg-intézmény számára hozzáférhető, így alacsony hazai alkalmazási arányuk nem meglepő. Másrészt 2009től már elérhetők a karbapenemek generikumai, s ezáltal egy hatóanyaggal megoldható elfogadható(bb) terápiás költségú széles spektrumú empirikus antibakteriális terápia súlyos állapotú betegek esetén, ami felváltotta a korábbi béta-laktám + aminoglikozid kombinációs terápiát.

Mivel a szelekciós nyomás csökkentésére a minél heterogénebb antibiotikum-használat (a különböző antibiotikumok kiegyensúlyozott alkalmazási aránya) a kívánatos [20-22], így a legközkedveltebb hatóanyag (amoxicillin-klavulánsav) egyre növekvő részesedése aggodalomra ad okot.

\section{Következtetés}

A hazai kórházi antibiotikum-felhasználás - európai viszonylatban - mennyiségileg rendkívül alacsony. Ez, illetve a felhasználás mintázatában tapasztalt, nemzetközi mércével is alátámasztott alul- (például szúk spektrumú penicillinek) vagy felülreprezentált felhasználás (például kinolonok, harmadik generációs cefalosporinok) további részletesebb (például kórház-, osztály-, illetve betegszintû) vizsgálatokat igényel.

Anyagi támogatás: A közlemény megírása anyagi támogatásban nem részesült.

Szerzői munkamegosztás: B. R., M. M.: Koncepció. B. R., M. M., S. Gy., H. E.: Szakmai értelmezés. B. R., M. M., V. R., D. P., B. A.: Adatfeldolgozás. B. R., M. M., V. R., B. A.: A kézirat megírása. A cikk végleges változatát valamennyi szerző elolvasta és jóváhagyta.

Érdekeltségek: A szerzőknek nincsenek érdekeltségeik.

\section{Irodalom}

[1] World Health Organisation: Antimicrobial resistance. Global Report on Surveillance. 2014. http://www.who.int/drugresistance/documents/surveillancereport/en/

[2] European Centre for Disease Prevention and Control, European Medicines Agency: The bacterial challenge: time to react. A call to narrow the gap between multidrug-resistant bacteria in the EU and the development of new antibacterial agents 2009. Available from: http://ecdc.europa.eu/en/publications/Publications/ 0909_TER_The_Bacterial_Challenge_Time_to_React.pdf

[3] Centers for Disease Prevention and Control: Core Elements of Hospital Antibiotic Stewardship Programs. CDC, 2014. http:// www.cdc.gov/getsmart/healthcare/ implementation/core-elements.html

[4] Elseviers, M., Wettermark, B., Almarsdóttir, A., et al.: Drug utilization research: Methods and applications. First edition. WileyBlackwell, Chichester, West Sussex, 2016.

[5] World Health Organization: ATC/DDD Index, 2016. WHO Collaborating Centre for Drug Statistics Methodology. http:// www.whocc.no/

[6] Vander Stichele, R. H., Elseviers, M. M., Ferech, M., et al.: Hospital consumption of antibiotics in 15 European countries: results of 
the ESAC retrospective data collection (1997-2002). J. Antimicrob. Chemother., 2006, 58(1), 159-167.

[7] Tasks of the National Health Insurance Fund of Hungary: Hospital's patient turnover data, 1996-2015. [Országos Egészségbiztositási Pénztár: Kórházi ágyszám- és betegforgalmi kimutatás, 2013.][Hungarian]

[8] Hungarian Central Statistical Office: Population data. [Központi Statisztikai Hivatal: Népesség, népmozgalom (1900-).] http:// www.ksh.hu/docs/hun/xstadat/xstadat_hosszu/h_wdsd00la. html [Hungarian]

[9] European Surveillance of Antimicrobial Consumption Network (ESAC-Net): ESAC-Net Interactive Database: Available from: http://ecdc.europa.eu/en/activities/surveillance/ESAC-Net/ Pages/index.aspx

[10] Benkó, R., Matuz, M., Doró, P., et al.: Antibiotic consumption between 1996 and 2003: national survey and international comparison. [Antibiotikum-felhasználás 1996-2003 között: hazai áttekintés és nemzetközi kitekintés.] Orv. Hetil., 2006, $147(26)$, 1215-1222. [Hungarian]

[11] Matuz, M., Benko", R., Hajdú, E., et al.: Evaluation of ambulatory antibiotic use in Hungary using drug-specific quality indicators. [A hazai ambuláns antibiotikum-alkalmazás minőségi indikátorok szerinti értékelése (1996-2010).] Orv. Hetil., 2013 154(24), 947-956. [Hungarian]

[12] Hajdú, E., Benkö, R., Matuz, M., et al.: Microbiological service for intensive care units in Hungary. [Milyen mikrobiológiai laboratóriumi háttér áll rendelkezésre az intenzív betegellátást végző osztályok számára?] Orv. Hetil., 2009, 150(22), 1037-1042. [Hungarian]

[13] Ludwig, E., Szalka, A.: Infectiology. [Infektológia.] Medicina Könyvkiadó, Budapest, 2009. [Hungarian]

[14] Gilbert, D. N., Moellering, R. C., Eliopoulos, G. M., et al.: The Sanford Guide to Antimicrobial Therapy, 2004. 34th edition. Antimicrobial Therapy, Hyde Park, VT, 2004.
[15] Gyires, K., Fürst, Zs.: Pharmacology. Chapter 53. [Farmakológia. 53. fejezet]. Medicina Könyvkiadó, Budapest, 2007. [Hungarian]

[16] De Lastours, V., Fantin, B.: Impact of fluoroquinolones on human microbiota. Focus on the emergence of antibiotic resistance. Future Microbiol., 2015, 10(7), 1241-1255.

[17] Weber, S. G., Gold, H. S., Hooper, D. C., et al.: Fluoroquinolones and the risk for methicillin-resistant Staphylococcus aureus in hospitalized patients. Emerg. Infect. Dis., 2003, 9(11), 1415-1422.

[18] Gbaguidi-Haore, H., Dumartin, C., L'Hériteau, F., et al.: Antibiotics involved in the occurrence of antibiotic-resistant bacteria: a nationwide multilevel study suggests differences within antibiotic classes. J. Antimicrob. Chemother., 2013, 68(2), 461-470.

[19] European Centre for Disease Prevention and Control: Antimicrobial resistance surveillance in Europe 2014. Annual Report of the European Antimicrobial Resistance Surveillance Network (EARS-Net). ECDC, Stockholm, 2015. http://ecdc.europa. $\mathrm{eu} / \mathrm{en} /$ activities/surveillance/esac-net/Pages/index.aspx

[20] Piper, G. L., Kaplan, L. J.: Antibiotic heterogeneity optimizes antimicrobial prescription and enables resistant pathogen control in the intensive care unit. Surg. Infect., 2012, 13(4), 194-202.

[21] Sandiumenge, A., Diaz, E., Rodriguez, A., et al.: Impact of diversity of antibiotic use on the development of antimicrobial resistance. J. Antimicrob. Chemother., 2006, 57(6), 1197-1204.

[22] Bonten, M. J., Austin, D. J., Lipsitch, M.: Understanding the spread of antibiotic resistant pathogens in hospitals: mathematical models as tools for control. Clin. Infect. Dis., 2001, 33(10), 1739-1746.
(Benkő Ria dr., Szeged, Szikra u. 8., 6725 e-mail: ria.benko@pharm.u-szeged.hu; benkoria@gmail.com)

Az Orvosi Hetilap 2016, 157, 1616. oldalán (40. szám) megjelent OH-Kvízre két helyes megfejtés érkezett.

A beküldők: Dr. Pallos Ágnes (Budapest) és Dr. Somogyi Erzsébet (Miskolc).

A nyerteseknek szívből gratulálunk.

A nyereményüket - egy, az Akadémiai Kiadó webáruházában

kedvezményes vásárlásra jogosító kupont - e-mailen küldjük el. 